\title{
Investigation of serum Amyloid A, haptoglobin and fibrinogen levels in sheep infected with Fasciola hepatica
}

\author{
V. Denizhan ${ }^{1}$, S. Kozat ${ }^{2 *}$ and A.B. Yilmaz ${ }^{3}$
}

\footnotetext{
${ }^{1}$ Medical Laboratory Techniques Dept., Özalp Vocational School, ${ }^{2}$ Department of internal diseases, Faculty of veterinary, ${ }^{3}$ Midwifery Department, Van Health Vocational School, Van Yuzuncu Yil University, Zeve Campus, 65080 Van-Turkey, *Corresponding Author: E-mail: skozat@hotmail.com; Phone: +90 5335525466
}

Journal of Livestock Science (ISSN online 2277-6214) 10: 53-58

Received on 30/5/2019; Accepted on 20/7/2019

doi. 10.33259/JLivestSci.2019.53-58

\begin{abstract}
The present study aimed to determine the changes in serum haptoglobin, serum amyloid A and fibrinogen levels in pathological disorders of sheep liver with Fasciola hepatica. Sixty sheep (50 with fascioliasis and 10 healthy) were used in the present study. Statistical analysis results demonstrated that SAA, Hp and fibrinogen concentration levels of the sheep infected with Fasciola hepatica were higher when compared to SAA, Hp and fibrinogen concentration levels in healthy sheep ( $\mathrm{P}<0.05$ ). While ALT, AST and GGT values of sheep infected with Fasciola hepatica were found to be higher than those of the healthy sheep, serum TP, ALB and glucose levels were lower. In statistical analysis, it was found that WBC, Neu and Eo values of sheep infected with Fasciola hepatica were higher when compared to WBC, Neu and Eo values in the control group. In conclusion, serum haptoglobin, serum amyloid A, and fibrinogen levels were significantly higher in sheep infected with Fasciola hepatica when compared to the healthy group. Due to the fact that increases in serum haptoglobin, serum amyloid A and fibrinogen levels in sheep with fasciolosis were similar to those observed in liver disorders, it was suggested that these parameters could be useful in determination of the liver damage levels and prognosis and in studies on liver disorders.
\end{abstract}

Keywords: sheep; Fasciola hepatica; haptoglobin; serum Amyloid A; fibrinogen 


\section{Introduction}

Livestock industry is an important and traditional sector in the agricultural economy of Turkey (Tuncer et al 2018, Tuncer 2019). Fasciolosis is a liver disease caused by trematodes of the Fasciolidae family, especially by the Fasciola hepatica and F. gigantica species (Tinar and Korkmaz, 2003; Zhang et al., 2005). Turkey is suitable for propagation of Fasciola species because of its climatic and ecological factors, but only $F$. hepatica and $F$. gigantica have been reported in Turkey. Fasciolosis leads to significant pathological disorders in the liver (Toparlak and Gül, 1988; Gargili et a.,l 1999).

Acute-phase proteins are produced by liver (Ceciliani et al., 2012). The function of these proteins is to protect the organism from further injuries, to eliminate infectious agents, to remove harmful molecules and residues for the organism, to activate a repair process necessary for the organism to recover its normal functions, and to maintain homeostasis (Pfeffer et al., 1993; Ulutas and Ozpinar, 2006). Several studies have been conducted on acute-phase protein levels in various diseases in veterinary science (Ganheim et al., 2007), and it was reported that serum amyloid A (SAA) was one of the initial acutephase proteins in Theileria annulata induced infections in cattle and could be used as an indicator of inflammatory reaction. Biochemical parameter levels are used as significant reference in the assessment of animal health and diagnosis of disease (Kragsbjerg et al., 1995).

Fibrinogenis a substrate promoter for fibrin formation and has tissue-production, restorative and clot-forming tasks that mediate the migration of inflammatory cells to the site of inflammation (Gruys et al., 2005). Fibrinogen is synthesized by the liver in reaction to the acute-phase response (Cray et al., 2009) and its levels in healthy cattle vary between 200 and $700 \mathrm{mg} / \mathrm{dl}$ (Gruys et al., 1994). Fibrinogen levels generally increase in infectious, purulent, traumatic, and neoplastic diseases and are used as a nonspecific marker for the determination of tissue damage and inflammation when calculated along with the erythrocyte sedimentation rate (Gruys et al., 2005). Fibrinogen has been used as an indicator of inflammatory disease in cattle for several years (Eckersall and Conner, 1988). Albumin is responsible for $75 \%$ of the plasma osmotic pressure and is the main amino acid source that can be used by the animal when necessary (Cerón et al., 2005). It has been reported that it can be used to evaluate the effect of collection and transportation stress on animals infected with experimental Dictyocaulus viviparus (Ganheim et al., 2004).

Although a specific elevation in liver enzymes and changes in other serum metabolites due to common liver parasite infections (Fasciola hepatica) have been extensively investigated in ruminants, there are no studies on serum haptoglobin, serum amyloid A, and fibrinogen levels in sheep. The present study aims to determine the changes in serum haptoglobin, serum amyloid A, and fibrinogen levels in sheep with fasciolosis that leads to important pathological disorders in the liver which is responsible for synthesis, metabolism, and detoxification.

\section{Material and Methods}

The present study was conducted on a total of 60 sheep from four sheep flocks belonging to different private farms. Fifty sheep were naturally infected with Fasciola hepatica and Fasciola hepatica antibodies were present in serum samples obtained from blood samples determined by using ELISA kit. Besides 10 clinically healthy sheep were used as control group. According to ELISA tests, Fasciola hepatica was negative in control group. After determining Fasciolosis and control groups of the study. Stool samples of approximately 30-50 g were collected from the rectum of sheep with probable fascioliasis into stool collection containers. Samples were numbered based on pedigree information. The samples were transported to the laboratory and kept at $-20{ }^{\circ} \mathrm{C}$ until the time of the tests. The Benedek sedimentation method was used in the examination of the stool samples (Toparlak and Tüzer 1994). This research was approved (28/12/2017 and 27552122604.01.02-E.91877) by the Animal Research Ethics Committee of Van Yuzuncu Yil University in Van, Turkey.

\section{Hematological analysis}

Blood samples were taken from the jugular vein into EDTA tubes and stored at $+4^{\circ} \mathrm{C}$. Samples were analyzed within 4 h. Total white blood cells (WBC), lymphocyte (Lym), monocytes (Mon), neutrophil (Neu), eosinophil (Eo) red blood cells (RBC), mean corpuscular volume (MCV), hematocrit (Hct), and hemoglobin (Hb). Hematologic parameters were determined by using a blood count device (Veterinary MS4-S-Melet Schloesing Laboratories in France).

\section{Biochemical analysis}

Blood was drawn from jugular vein into anti-coagulant free tubes. Blood samples in the anticoagulant-free tubes were centrifuged at $1400 \times \mathrm{g}$ for $10 \mathrm{~min}$ (Rotofix32®-Hettich), and their serums were extracted. Sera were frozen in Eppendorf tubes at $-20^{\circ} \mathrm{C}$. Serum haptoglobulin (Bovine Haptoglobin ELISA Kit, Catalog No: 201-04-0121), Serum amyloid A (Bovine SAA ELISA Kit, Catalog No: 201-04-0126), and fibrinogen levels (Bovine Fibrinogen, ELISA Kit, Catalog No: 201-04-0086) were determined with ELISA device (ELISA reader®-DAS) based on the method specified in commercial test kits. Serum alanine transaminase (ALT), aspartate aminotransferase (AST), gamma glutamyltransferase (GGT), total protein (TP), albumin (Alb) and glucose (GLU) levels were measured with auto analyzer (BS-120 VetMindray). 


\section{Statistical Analysis}

Descriptive statistics on biochemical parameters for the sheep with fascioliasis and healthy sheep were expressed as Mean, Standard Deviation, Minimum and Maximum values. Kruskal-Wallis test was used to compare the biochemical parameters between the groups. Duncan multiple comparison test was used to identify differences between the groups. Spearman correlation coefficient was calculated separately for the groups to determine the correlation between these variables. The statistical significance level was accepted as 5\% and the SPSS statistical software (ver 2.0) was used for the calculations.

\section{Results}

Hematological parameters are summarized in Table 1. In statistical analysis, significantly lower number of RBC, $\mathrm{Hb}, \mathrm{Hct}$, and MCV were recorded in sheep from the infected with Fasciola hepatica, whereas WBC, Neu, and eosinophils were significantly higher than in the control group. There were no significant changes in lymphocytes, and monocyte count between the infected and non-infected group. Biochemical results are presented in Table 2. In sheep sera from the infected with Fasciola hepatica had significantly higher ALT, AST and GGT levels, serum total protein, albumin and glucose values were significantly lower than in control group. Serum amyloid A, Hp and fibrinogen concentration levels of sheep infected with Fasciola hepatica were higher than control group $(\mathrm{P}<0.05)$.

Table 1. Hematological parameters in sheep infected with Fasciola hepatica and healthy sheep

\begin{tabular}{|c|c|c|}
\hline Parameter & $\begin{array}{c}\text { Control } \\
\overline{\mathbf{x}} \pm \text { SD }\end{array}$ & $\begin{array}{c}\text { F. hepatica } \\
\overline{\mathbf{x}} \pm \text { SD }\end{array}$ \\
\hline $\mathrm{WBC}\left(10^{3} / \mathrm{mm}^{3}\right)$ & $8.65 \pm 0.69^{\mathrm{a}}$ & $14.59 \pm 2.84^{\mathbf{b}}$ \\
\hline $\mathrm{Lym}\left(10^{3} / \mathrm{mm}^{\mathbf{b}}\right)$ & $2.33 \pm 0.53^{\mathrm{a}}$ & $3.45 \pm 2.31^{\mathrm{a}}$ \\
\hline $\mathrm{Mon} .\left(10^{3} / \mathrm{mm}^{3}\right)$ & $0.69 \pm 0.20^{\mathrm{a}}$ & $0.64 \pm .19^{\mathrm{a}}$ \\
\hline $\mathrm{Neu}\left(10^{3} / \mathrm{mm}^{3}\right)$ & $5.40 \pm 0.71^{\mathrm{a}}$ & $8.96 \pm 2.25^{\mathbf{b}}$ \\
\hline $\mathrm{Eo}\left(10^{3} / \mathrm{mm}^{3}\right)$ & $0.37 \pm 0.23^{\mathrm{a}}$ & $0.75 \pm 0.10^{\mathbf{b}}$ \\
\hline $\mathrm{RBC}\left(10^{6} / \mathrm{mm}^{3}\right)$ & $10.31 \pm 1.52^{\mathrm{a}}$ & $9.37 \pm 0.44^{\mathbf{b}}$ \\
\hline $\mathrm{MCV}$ & $27.73 \pm 1.28^{\mathrm{a}}$ & $27.15 \pm 2.01^{\mathrm{b}}$ \\
\hline $\mathrm{Hct}(\%)$ & $28.96 \pm 4.61^{\mathrm{a}}$ & $24.40 \pm 2.13^{\mathrm{b}}$ \\
\hline $\mathrm{Hb}(\mathrm{g} / \mathrm{dl})$ & $11.26 \pm 1.98^{\mathrm{a}}$ & $9.10 \pm 0.93^{\mathbf{b}}$ \\
\hline
\end{tabular}

$\bar{X} \pm S D$ : mean \pm standart deviation; a, b: Different lower cases in the same column represent statistically significant differences $\quad(P<0.05)$.

Table 2. Biochemical parameters in sheep infected Fasciola hepatica and healthy sheep

\begin{tabular}{|c|c|c|}
\hline Parameter & $\begin{array}{c}\text { Control } \\
\overline{\mathbf{x}} \pm \text { SD }\end{array}$ & $\begin{array}{c}\text { F. hepatica } \\
\overline{\mathbf{x}} \pm \text { SDD }\end{array}$ \\
\hline ALT (U/L) & $18.64 \pm 3.44^{\mathbf{a}}$ & $32.45 \pm 6.77^{\mathbf{b}}$ \\
\hline AST(U/L) & $105.36 \pm 9.88^{\mathbf{a}}$ & $167.79 \pm 65.36^{\mathbf{b}}$ \\
\hline GGT(U/L) & $53.58 \pm 5.91^{\mathbf{a}}$ & $87.07 \pm 23.13^{\mathbf{b}}$ \\
\hline TP (g/dl) & $6.36 \pm 1.32^{\mathrm{a}}$ & $4.73 \pm .88^{\mathbf{b}}$ \\
\hline Alb (g/dl) & $2.61 \pm 0.79^{\mathrm{a}}$ & $1.62 \pm 0.64^{\mathrm{b}}$ \\
\hline GLU (mg/dl) & $60.65 \pm 13.10^{\mathrm{a}}$ & $46.41 \pm 12.16^{\mathbf{b}}$ \\
\hline Serum Amyloid A (ng/L) & $2.68 \pm 0.21^{\mathrm{a}}$ & $16.29 \pm 8.18^{\mathrm{b}}$ \\
\hline Fibrinogen (ng/L) & $7.80 \pm 3.13^{\mathrm{a}}$ & $16.65 \pm 5.80^{\mathrm{b}}$ \\
\hline Haptoglobin (ng/L) & $76.08 \pm 39.99^{\mathrm{a}}$ & $185.86 \pm 91.40^{\mathrm{b}}$ \\
\hline
\end{tabular}

\section{Discussion}

The aim of the present study was to determine the changes in serum haptoglobin, serum amyloid A, and fibrinogen levels in sheep with fasciolosis that lead to significant pathological disorders in liver which has functions such as synthesis, metabolism, and detoxification.

Fasciolosis is diagnosed with clinical and autopsy findings, stool examination methods, biochemical analyzes, imaging techniques and serologic methods in animals (Tinar and Korkmaz, 2003). Furthermore, it was reported that the changes in serum AST, GLDH and GGT activities are important in the assessment of the different stages of $F$. hepatica 
infection (Benchaoui et al., 1993; Yang et al., 1998). In another study, it was reported that the increases in GLDH and GGT activities were sensitive markers for liver damage due to migration of developing trematodes (Vengušt et al., 2003), while it is known that AST is a less sensitive marker for liver injury (Sykes et al., 1980; Kozat and Denizhan, 2010). Ferre et al (1994) reported that the increases in AST and GLDH enzyme activities occurred during the migration of young trematodes through the liver parenchyma, while GGT increased during the penetration of trematodes into the bile ducts. In the present study, AST, ALT and GGT serum activities in sheep infected with $F$. hepatica were significantly higher when compared to the control group. Increases in serum AST, ALT, and GGT activities in sheep infected with $F$. hepatica were consistent with the previous study findings (Sykes et al., 1980; Benchaoui et al., 1993; Ferre et al., 1994; Yang et al., 1998; Vengušt et al., 2003; Kozat et al., 2006; Mert et al., 2006; Kozat and Denizhan, 2010).

Cellular immune response against $F$. hepatica infection is widely used in various animals (Mert et al., 2006). It was reported that peripheral blood eosinophil count increases in sheep infected with $F$. hepatica and $F$. gigantica (Zhang et al., 2005). In another study, it was reported that $\mathrm{Hb}$ and Hct levels decreased in sheep infected with $F$. hepatica (Hawkins 1984). In the present study, it was determined that WBC, Neu and Eo values were higher in sheep infected with Fasciola hepatica when compared to the control group WBC, Neu and Eo values. Hematological findings of the present study were consistent with the findings reported in the literature (Hawkins, 1984, Zhang et al., 2005, Mert et al., 2006).

Acute phase proteins are used as parameters in various inflammation, infection and trauma cases, in the evaluation of the immune system response, and in the prognosis and diagnosis of several diseases (Gruys et al., 1994, Kent 1992). Several studies reported that serum amyloid A, serum haptoglobin, ceruloplasmin, and fibrinogen concentrations increased due to several infections and inflammatory cases in ruminants (Conner and Eckersall 1988; Conner et al., 1989; Pfeffer et al., 1993; Ganheim et al., 2003; Wells et al., 2013). In an experimental study, it was reported that serum Hp and SAA levels did not increase during common gastrointestinal nematode infections in sheep, while serum Hp and SAA concentrations increased in liver trematode infection and Johns disease (Ganheim et al., 2004). In another study, it was reported that SAA was one of the first emerging acute phase proteins in Theileria annulata infections in cows and it could be used as an indicator of inflammatory reaction (Glass et al., 2003; Nazifi et al., 2008; Başbuğ and Gül, 2011). It was reported that calves infected with Dictyocaulus viviparus are reported to increase in acute phase proteins (APP) haptoglobin, serum amyloid A (SAA) and fibrinogen levels (Ganheim et al., 2004). In the present study, it was found that SAA, Hp and fibrinogen concentrations were higher in sheep infected with Fasciola hepatica compared to SAA, Hp and fibrinogen concentrations in healthy sheep $(\mathrm{P}<0.05)$. The increased SAA, Hp, and fibrinogen concentrations determined in the present study in sheep infected with Fasciola hepatica were consistent with other studies (Conner and Eckersall, 1988; Conner et al., 1989, Pfeffer et al., 1993; Ganheim et al., 2003; Ganheim et al., 2004; Wells et al., 2013).

Serum albumin is a negative acute phase protein (Thomas, 2000, Tothova et al., 2014) synthesized in the liver (Kozat and Sepehrizadeh, 2017), and it is the most important extracellular antioxidant due to the thiol group content (Halliwell, 1988). The albumin synthesis is decreased in liver infections and injuries (Thomas 2000). In the present study, it was found that the total protein and albumin levels in $F$ hepatica infected sheep were lower when compared to the control group (Halliwell, 1988; Thomas, 2000). It was also found that serum haptoglobin, amyloid A, and fibrinogen levels were higher in sheep infected with Fasciola hepatica than those of the healthy sheep, whereas serum total protein and albumin levels were lower compared to the control group. Increased acute phase protein levels in sheep with fasciolosis suggested that the decrease in total protein and albumin levels could be caused by pathological liver disorders.

In conclusion, the increases in serum haptoglobin, serum amyloid A, and fibrinogen levels in sheep with fasciolosis were similar to liver disorder findings and it is suggested that these parameters could be useful in the evaluating degree and prognosis of liver damage and could shed light on future studies on liver disorders.

\section{Acknowledgement}

This study was financed by Van Yuzuncu Yil University, Scientific Research Projects Coordination Unit, Project number TSA -2018-6796.

\section{References}

1) Başbuğ O, Gül Y. 2011. Investigations on hemolysis in cows with Tropical Theileriosis. Journal of the Faculty of Veterinary Medicine, Kafkas University 17, 421-427.

2) Benchaoui HA, Mckellar QA. 1993. Effect of early treatment with rafoxanide on antipyrine clearance in sheep infected with Fasciola hepatica. Xenobiotica 23, 439-448.

3) Ceciliani F, Ceron JJ, Eckersall PD, Sauerwein H. 2012. Acute phase proteins in ruminants. Journal of Proteomics 75(14), 4207-4231.

4) Cerón JJ, Eckersall PD, Martínez-Subiel S. 2005. Acute phase proteins in dogs and cats: current knowledge and future perspectives. Veterinary Clinical Pathology 34(2), 85-99. 
5) Conner JG, Eckersall PD, Wiseman A, Bain RK, Douglas TA. 1989. Acute phase response in calves following infection with Pasteurella haemolytica, Ostertagia ostertagi and endotoxin administration. Research in Veterinary Science 47, 203-207.

6) Conner JG, Eckersall PD. 1988. Bovine acute phase response following turbentine injection. Research in Veterinary Science 44, 82-88.

7) Cray C, Zaias J, Altman NH. 2009. Acute phase response in animals: a review. Comparative Medicine 59, 517-526.

8) Eckersall PD, Conner JG. 1988. Bovine and canine acute phase proteins. Veterinary Research Communications 12, 169178.

9) Ferre I, Barrio JP, Gonzalez-Gallego J, Rojo-Vazquez FA. 1994. Appetite depression in sheep experimentally infected with Fasciola hepatica. Veterinary Parasitology 55, 71-79.

10) Ganheim C, Alenius S, Waller KP. 2007. Acute phase proteins as indicators of calf herd health. Veterinary Journal 173, 645-651.

11) Ganheim C, Höglund J, Waller KP, 2004. Acute phase proteins in response to Dictyocaulus viviparous infection in calves. Acta Veterinaria Scandinavica 45, 79-86.

12) Gånheim C, Hulten C, Carlsson U, Kindahl H, Niskanen R, Waller KP, 2003. The acute phase response in calves experimentally infected with bovine viral diarrhoea virus and/or Mannheimia haemolytica. Journal of Veterinary Medicine Series B 50, 183-190.

13) Gargılı A, Tüzer E, Gülanber A, Toparlak M, Efil İ, 1999. Prevalence of liver trematod infections in sheep and cattle slaughtered in Thrace. Turkish Journal of Veterinary and Animal Sciences 23, 115-116.

14) Glass EJ, Craigmile SC, Springbett A, Preston PM, Kirvar E, Wilkie GM, Brown CD, 2003. The protozoan parasite, Theileria annulata, induces a distinct acute phase protein response in cattle that is associated with pathology. International Journal for Parasitology 33, 1409-1418.

15) Gruys E, Oblowo MJ, Toussaint JM. 1994. Diagnosis significance of major acute phase proteins in veterinary clinical chemistry: a review. Bulletin of the Veterinary Institute in Pulawy 64, 1009-1015.

16) Gruys E, Toussaint MJM, Niewol TA, Koopmans SJ, 2005. Acute phase reaction and acute phase proteins. Journal of Zhejiang University Science A 11, 1045.

17) Halliwell B, 1988. Albumin, an important extracellular antioxidant. Biochemical Pharmacology 37, 569-71.

18) Hawkins CD, 1984. The use of haemoglobin, packed-cell volume and serum sorbitol dehydrogenase as indicators of the development of fascioliasis in sheep. Veterinary Parasitology 15, 125-133.

19) Kent J, 1992. Acute phase proteins: their use in veterinary diagnosis. British Veterinary Journal 148, $279-282$.

20) Kozat S, Denizhan V, 2010. Glucose, lipid, and lipoprotein levels in sheep naturally infected with Fasciola hepatica. Journal of Parasitology 96, 657-659.

21) Kozat S, Ekin S, Kaya A, Denizhan V, 2006. Serum adenosine deaminase activity and biochemical parameters in chronic Fascioliasis in sheep. Indian Veterinary Journal 83, 249-50.

22) Kozat S, Sepehrizadeh E, 2017. Methods of diagnosing in liver diseases for dog and cats. Turkish Journal of Scientific Reviews 10 (2), 36-46.

23) Kragsbjerg P, Jones I, Vikerfors T, Holmberg H. 1995. Diagnostic value of blood cytokine concentrations in acute pneumonia. Thorax 50, 1253-1257.

24) Mert H, Kozat S, Ekin S, Mert N,Yörük I, 2006. Serum sialic acid, lipid-bound sialic acid levels in sheep naturally chronic infected with Fasciola hepatica. Yuzuncu Yil University Institute of Health Sciences. 9, 40-46.

25) Nazifi S, Khoshvaght A, Gheisari HR, 2008. Evaluation of serum and milk amyloid A in some inflammatory diseases of cattle. Iranian Journal of Veterinary Research 9, 222-226.

26) Pfeffer A, Rogers K.M, O'keeffe L, Osborn PJ, 1993. Acute phase protein response, food intake, liveweight change and lesions following intrathoracic injection of yeast in sheep. Research in Veterinary Science 55, 360-366.

27) Sykes AR, Coop RL, Robinson MG, 1980. Chronic subclinical ovine fascioliasis: Plasma glutamate dehydrogenase, gamma-glutamyl transpeptidase and aspartate aminotransferase activities and their significance as diagnostic aids. Research in Veterinary Science 28, 71-75.

28) Thomas JS, 2000. Overview of plasma proteins. In: Feldman BF, Zinkl JG, Jain NC, editors. Schalm"s Veterinary Hematology. Philadelphia: Lippincott Williams \& Wilkins p. 891-8.

29) Tinar R, Korkmaz M, 2003. Fasciolosis. Turkey Parasitology Association, Publication. No. 18, Istanbul.

30) Toparlak M, Gül Y, 1988. Investigations on liver trematod infections in sheep slaughtered in Van province municipal slaughterhouse. Veterinary Journal of Ankara University 35, 269-274.

31) Toparlak M, Tüzer E, 1994 Laboratory Techniques in the Diagnosis of Parasitic Diseases. Istanbul University Faculty of Veterinary Medicine Publication, Istanbul. p.19.

32) Tothova C, Nagy O, Kovac G.2014. Acute phase proteins and their use in the diagnosis of diseases in ruminants: a review. Veterinary Medicine 59, 163-180.

33) Tuncer SS, Uslu S, Taş A, Şireli HD, 2018. The densities of fiber follicles in the Karakaç, Norduz, and Zom sheep and a comparative analysis. Austral Journal of Veterinary Sciences 50, 21-26. 
34) Tuncer SS, 2019. An investigation of the lead and cadmium levels of blood serum and wool of White Karaman sheep in the Van region (Turkey). Applied Ecology and Environmental Research 17, 1381-1387.

35) Ulutas PA, Ozpinar A, 2006. Effect of Mannheimia (Pasteurella) haemolytica infection on acute-phase proteins and some mineral levels in colostrum-breast milk-fed or colostrum-breast milk-deprived sheep. Veterinary Research Communications 30, 485-495.

36) Vengušt G, Klinkon M, Bidovec A, Vengušt A, 2003. Fasciola hepatica: effects on blood constituents and liver minerals in fallow deer (Damadama). Veterinary Parasitology 112, 51-61.

37) Wells B, Innocent GT, Eckersall PD, McCulloch E, Nisbet AJ, Burgess ST, 2013.Two major ruminant acute phase proteins, haptoglobin and serum amyloid A, as serum biomarkers during active sheep scab infestation. Journal of Veterinary Research 44, 103.

38) Yang Q, Mao WH, Ferre I, Bayón JE, Mao XZ, González-Gallego J. 1998. Plasma aspartate aminotransferase (AST), glutamate dehydrogenase (GLDH) and gamma-glutamyl transpeptidase (GGT) activities in water buffaloes with experimental subclinical fasciolosis. Veterinary Parasitology 78, 129-136.

39) Zhang WY, Moreau E, Hope JC, Howard CJ, Huang WY, Chauvin A, 2005. Fasciola hepatica and Fasciola gigantica: Comparison of cellular response to experimental infection in sheep. Experimental Parasitology 111, 154-159. 